\title{
Edukacja retoryczna jako element kształtowania mądrości politycznej
}

\author{
Aleksandra Mathiesen \\ (Uniwersytet im. Adama Mickiewicza w Poznaniu, aleksandramathiesen@gmail.com)
}

\section{Polityka i retoryka - nowa pajdeja}

Początk w sztuki retorycznej (rhetorike techne) większoB badaczy upatruje w okresie działalnoci autor w m w sądowych (Tizjasza, Koraksa) oraz sofist w (m.in. Protagorasa czy Gorgiasza). Jej rozw j związany był z wyłanianiem się demokratycznych struktur w Syrakuzach, a poóźniej Atenach, a w konsekwencji z rosnącą wśród obywateli potrzebą werbalnej ekspresji roszczeń i projektów o charakterze politycznym - współudziału w kształtowaniu politei (Thomas, Webb 1994, 5). Pośród licznych równoś ciowych postulatów demokratycznej społeczności Aten: isogonii (równości podług urodzenia), isokratii (równości w sprawowaniu rządów), isonomii (ró wność wobec prawa) oraz isegorii (równe prawo do przemawiania w kwestiach ważnych dla polis), najbardziej interesujący w świetle niniejszych rozważań jest ten ostatni. Isegoria bezpośrednio odnosiła się do przysługującego każdemu obywatelowi uprawnienia do zabierania głosu w jakichkolwiek sprawach natury politycznej, np. podczas spotkań Zgromadzenia Ludowego. Mogens Herman Hansen w książce The Athenian Democracy in the Age of Demosthenes wskazywał ponadto, że podczas gdy równość wobec prawa (isonomía) wynikała zarówno z „przyrodzenia” (przynależna obywatelom z urodzenia lub ewentualnie nadania, jako nominalny przywilej polityczny), jak $\mathrm{i}$ z jej realnego użytkowania w ramach działalności obywatelskiej, tak swoboda (eleuthería) wypowiedzi objawiała się w większej mierze poprzez uchwycenie konkretnej możliwości (equality of opportunity) w ramach korzystania z przynależnych uprawnień (Hansen 1991, 83). Powyższe rozgraniczenie wskazuje przede wszystkim na ró żnice pomiędzy dostępem do swobód związanych $\mathrm{z}$ postulatami równościowymi i ich rzeczywistym kultywowaniem.

Choć obowiązywało powszechne dla wszystkich obywateli prawo do zabierania głosu w sprawach polis, możiliwość korzystania z niego stawała się 
udziałem tych, którzy posiadali określone umiejętności i kompetencje. Skuteczność i powodzenie politycznych działań zależały wszakże w dużej mierze od wypracowania prawdziwej doskonałości (areté) w zakresie sztuki wymowy i perswazji. W związku z rosnącym zapotrzebowaniem na nowego rodzaju edukację pojawili się profesjonalni nauczyciele oferujący swoje usługi w zakresie nauczania sztuki politycznej, w tym także gładkiego i przekonywującego wypowiadania się przed ogółem obywateli. Zajęciem tym parali się wędrowni mędrcy zwani sofistami, którzy, pomimo dzielących ich różnic programowych, zgodnie wierzyli, że zarówno cnót politycznych, jak i wszelkich powiązanych z nimi umiejętności, można młodzieńców helleńskich wyuczyć. Na kanwie własnych rozważań mędrcy komponowali zatem autorskie programy pajdeutyczne obejmujące także sztukę wymowy i perswazji.

Jeden $\mathrm{z}$ najbardziej znanych ze swych poglądów i działalności sofistów, Protagoras, przekonywał, że choć ważne z punktu widzenia politycznego i społecznego poczucie wstydu i poczucie prawa były darem bogów, a zatem przypadały $\mathrm{z}$ natury wszystkim ludziom, tak dojrzałe dzielności obywatelskie kształtowały się poprzez właściwe wychowanie. Twierdził ponadto, że ujęta $\mathrm{w}$ pajdei idea obywatelskości, wzmacniająca poczucie obowiązku wobec wspólnoty, stawiająca na piedestale aktywne uczestnictwo w sprawach ważnych dla ogółu stanowi podstawę istnienia i funkcjonowania demokratycznej polis (por. Mielczarski 2010, 26-33). Ponadto:

Mądrość pojmował jako sprawność polityczną, czyli umiejętność przekonywania wspólnoty do rzeczy dla niej pożytecznych. Państwo idzie właściwą drogą za sprawą mędrca, który potrafi przekonać społeczność do tego, co dobre. Według relacji Platona Protagoras traktował „dobrych polityków” jako „ludzi mądrych”, którzy potrafią nakłonić obywateli swego miasta do tego, co pożyteczne i sprawiedliwe (Mielczarski 2010,36).

Przede wszystkim należy zauważyć, że Protagorasa interesowała mądrość w jej wymiarze praktycznym i była ściśle powiązana z polityką, a przejawiała się w skutecznym działaniu obywateli, którzy potrafili wywierać wpływ na innych w sprawach ważnych z punktu widzenia wspólnoty. Stąd zarówno zdolność do postrzegania „tego, co pożyteczne i sprawiedliwe”, jak i umiejętność perswazyjnego ujmowania przedmiotu, stanowiły przejawy rozumności praktycznej, czyli politycznej. 
Sprawność w perswadowaniu, pośród innych dzielności obywatelskich, była dla Protagorasa umiejętnością priorytetową, co uzasadniały jego oparte na epistemicznym indywidualizmie i poznawczym relatywizmie poglądy. Tłumaczyły one bowiem podejście sofisty do kwestii stanowienia i obowiązywania praw oraz norm społecznych. Przywołana perspektywa odnosi się do postulatu anthrópos métron, wedle którego jednostki, a w konsekwencji także i społeczności, mogły kierować się różnorakimi mniemaniami, wartościami i racjami. Zwykle umiejętność przekonania do jednych oraz odwiedzenia od innych była kluczowa dla ich zaistnienia, usankcjonowania i funkcjonowania w społeczeństwie. Zasada ustanawiająca człowieka miarą wszechrzeczy była w istocie normą sądu (Reale 2005, 247) kształtującego rzeczywistość, zwłaszcza społeczną i polityczną (nómos), z jednej strony wedle przeforsowanych mniemań indywiduów, ale $\mathrm{z}$ drugiej podług kryterium politycznej użyteczności, wykraczającego poza sferę prywatnych interesów jednostki. Relatywizm norm i wartości postulowany przez Protagorasa nie przybierał zatem formy skrajnego indywidualizmu - mędrzec przekonywał, że pewne racje, sądy czy mniemania były słuszniejsze, pożyteczniejsze czy rozsądniejsze - i dlatego zasługiwały na wybór bardziej niż inne. $\mathrm{Z}$ tego względu, choć pozornie wydawałoby się, że obywatel, który w ramach swobody wypowiedzi i podług zaleceń sztuki perswazji wypowiadał się w kwestiach politycznych posiadał szeroki zakres autonomii, w rzeczywistości podlegał on silnym wpływom wspólnoty, jej tradycji oraz norm przekazanych w toku kształtowania cnót obywatelskich (Mielczarski 2010, 39).

Sofistyczne, a w szczególności Protagorejskie, zainteresowanie ludzkimi działaniami, obywatelskimi interakcjami, konsekwentnie: całokształtem politycznej praktyki i jej skutecznością, zainicjowało pojawienie się refleksji o charakterze pajdeutycznym, poszukującej sposobów kształtowania obywatelskich cnót podług zaleceń tzw. sztuki politycznej (politiké téchne). Dodatkowo, wnikliwe badanie nad lógoi jako formami wypowiedzi i ich mocą urzekania i przekonywania pozwoliło otworzyć refleksję polityczną i pajdeutyczną na nową, twórczą dziedzinę związaną z perswazją (Bons 2007, 39). Szczególny wymiar owe badania zyskały wśród tych, którzy sami siebie określali mianem filozofów. Dostrzegli oni potrzebę 
zrewidowania, systematyzacji i przeformułowania dokonań sofistów na tym polu. Przedstawili własne propozycje obywatelskiej, polityczno-retorycznej pajdei na nowym podłożu - refleksji filozoficznej.

Celem podjętych $\mathrm{w}$ niniejszym artykule dociekań będzie zbadanie filozoficznych uwarunkowań sztuki przekonywania, funkcjonującej w kontekście tzw. mądrości bądź sztuki politycznej, przez odwołanie się do pajdeutycznych poglądów trzech autorów: Platona, Izokratesa i Arystotelesa. Każdy z nich przedstawił własną filozoficzną koncepcję polityki i każdy z nich odnosił się do problemu retoryki $\mathrm{w}$ odniesieniu do autorskich propozycji wychowawczych. Podjęte przez nich próby umocowania retoryki w kontekście politycznym miały ogromne znaczenie dla pajdeutycznych modeli klasycznego okresu greckiej kultury i wniosły nowe spojrzenie na problem pogodzenia sztuki perswazji z wymogami szlachetnej praktyki obywatelskiej.

\section{Retoryka jako sztuka - uwagi wstępne}

Przed rozpoczęciem omawiania rozważań wspomnianych autorów należy uczynić kilka wstępnych uwag. Greckie słowa: rhetoriké, rhétores, jeśli już pojawiały się w oryginalnych tekstach Platona, Izokratesa czy Arystotelesa, nie zawsze odnosiły się do tego samego zakresu znaczeniowego, niekiedy pociągały za sobą skrajnie odmienne wartościowanie, innym zaś razem względną neutralność aksjologiczną. Ponadto tłumacze, a powołuję się tutaj na przekłady polskie oraz anglojęzyczne, różne greckie terminy i określenia odnoszące się do pewnej umiejętności czy biegłości w układaniu i wygłaszaniu perswazyjnych mów oddawali używając wielorakich sformułowań, niekoniecznie konsekwentnie. I tak, „retoryka”, „oratorstwo”, „sztuka wymowy”, „pajdeja słowa” czy „sprawczyni przekonywania” występują zamiennie lub w ewaluacyjnym przeciwstawieniu. Dopiero po przedstawieniu stosownych wyjaśnień definiujących i dookreślających termin „retoryka” w perspektywie badań nad pajdeutycznymi poglądami Platona, Izokratesa i Arystotelesa, można posługiwać się nim konsekwentnie i bez nadużyć. Tym bardziej, że przytaczane wykładnie są ze sobą powiązane - autorzy nieskrycie nawiązywali do siebie, w różnym stopniu krytykując i dając powody do krytyki i opiniowania. 
Retoryka stanowiąca przedmiot wspólnych dociekań była przede wszystkim istotnym elementem kształcenia w ogólnym zamyśle pajdeutycznym, odmiennie adaptowanym przez trzech myślicieli żyjących w V i IV w. p.n.e. (Wardy 1996, 2). Był to okres rozkwitającej demokracji ateńskiej, czasy walki o dominację na Półwyspie Peloponeskim, czas wewnętrznych konfliktów zmagających się frakcji i stronnictw. Nic więc dziwnego, że sztuka retoryczna „wciągnięta” została w starcie różnych aksjologii, oczekiwań i celów, a w konsekwencji różnych projektów filozoficznych i wychowawczych. Polemiczna rywalizacja Platona, Izokratesa i Arystotelesa stała się kluczowa w początkach rozwoju sztuki perswazji.

Wstępnie należy jednak wznieść się ponad podziały i rozróżnienia związane $\mathrm{z}$ odmiennym zapatrywaniem na miejsce retoryki $\mathrm{w}$ zamyśle pajdetycznym oraz działalności politycznej, aby na wspólnej kanwie uściślić pewien zakres znaczeń i odniesień, które zebrane pod wspólnym hasłem „retoryka” będą stanowić istotowy rdzeń tej umiejętności, jaka włączona została $\mathrm{w}$ refleksję tych trzech myślicieli zmagających się $\mathrm{z}$ wyzwaniem wychowania obywateli pólis.

Aby zrozumieć, czym była retoryka dla przywoływanych tu starożytnych mędrców, najpierw należy zdefiniować pojęcie sztuki w jej antycznym, greckim znaczeniu, które różniło się od współczesnej, angażującej wartości estetyczne refleksji. Na początek posłużę się w tym celu definicją Arystotelesa, jako że jest ona najbardziej ogólna, a przy tym precyzyjnie oddaje specyfikę myślenia antycznych Greków w tej tematyce. Sztuka antyczna była umiejętnością wytwórczą i opierała się na rozumowej dyspozycji do wytwarzania (Etyka Nikomachejska, 1140a). Wytwórczość polegała na wynajdywaniu właściwych środków mających zrealizować zamierzony cel, którym był wytwór sztuki. Toteż obok tak oczywistych dla nas kunsztów jak malarstwo, rzeźbiarstwo, poezja czy muzyka, sztukami były również wszelkie rzemiosła, a także medycyna, kosmetyka, kucharstwo czy retoryka.

Charakteryzując retorykę jako sztukę, należałoby określić, na jakiej umiejętności wytwórczej bazowała oraz co było jej celem. Posuwając się jednak o krok dalej, szukając w retoryce możliwości realizacji mądrości politycznej, trzeba również odpowiedzieć na pytanie wykraczające poza 
obszar charakterystyki retoryki jako umiejętności wytwórczej: czemu, w kontekście polityki, sztuka perswazji miałaby służyć?

Analizując dociekania Platona, Izokratesa i Arystotelesa w dziedzinie retoryki można wskazać poniższe punkty zbieżne odpowiadające potrzebom przedstawionego wyżej szkicu:

- po pierwsze: retoryka jako sztuka bazowała na umiejętności wytwórczej (poieín) lub potencji (dúnamis), której istotą było przekonywanie (peithó), znalezienie aspektów przekonujących co do danego przedmiotu;

- po drugie: przekonywanie jako funkcja mowy, z perspektywy specyficznego antycznego sposobu rozumienia sztuki, łączyła się $\mathrm{z}$ fenomenem wynalazczości, a zatem rozumowej zdolności do wytwarzania mów przekonywujących, które stanowiły wytwór tej sztuki; celem sztuki retorycznej było zatem uwiarygodnienie, uprawdopodobnienie, podtrzymanie logosu.

- po trzecie: retoryka była przedmiotem antycznej greckiej pajdei obejmującej troską wychowanie obywateli do rządów i funkcjonowania we wspólnocie; retoryka z konieczności opierała się zatem na pewnego rodzaju mądrości politycznej, jednocześnie będąc na niej ufundowaną, jak i przyczyniając się do jej wykształcenia.

Retoryka jako dyscyplina ufundowana na rozumowych dyspozycjach nie odnosiła się do konkretnego przedmiotu, co do którego miałaby wytworzyć przekonanie, lecz ogólniej: do perswazyjnej funkcji mowy (Gorgiasz, 453a, 449e; Retoryka, 1354a 12), a także do pewnej „psychologicznej” konstytucji człowieka jako istoty obdarzonej mową, narzędziem służącym do osiągania przedstawionych powyżej celów, a w konsekwencji również do wywołania pożądanych efektów, zwłaszcza w działalności politycznej. Jeśli wyeksponowane przez Arystotelesa w Polityce powiązanie mowy i działalności określanej jako práxis, czyli takiej, której celem było dobro polis jako wspólnoty, wyrażało się w formule: człowiek jest zwierzęciem politycznym zdolnym do wyrażania w mowie nie tylko tego, co sprawia przyjemność i przykrość, ale przede wszystkim tego, co sprawiedliwe i niesprawiedliwe, szlachetne i niegodziwe (Polityka, 1253a), wtedy retoryka stanowiła tyle ważne, co kłopotliwe narzędzie realizacji praktycznych celów 
wspólnoty polis. Jako taka stała się $\mathrm{z}$ konieczności przedmiotem pajdeutycznych rozważań antycznych mędrców.

Na pierwszy plan wysuwa się zatem refleksja nie nad immanentnym celem retoryki jako sztuki wytwarzaniem mów przekonywujących oraz sposobami osiągania tego celu, ale refleksja nad miejscem retoryki w procesie kształtowania obywatela, który dzięki niej stawał się istotnie „sprawcą przekonania" (peithoús demiurgós). Sztuka retoryczna poszukiwała skutecznych sposobów przekonywania, a zatem również sposobów wzbudzania zaufania ${ }^{1}$, w konsekwencji zatem - sposobów wywołania określonej reakcji: nakłonienia do wszczęcia lub zaniechania działań. ${ }^{2}$

Toteż nieobojętne dla „teoretyków” retoryki było zagadnienie właściwego edukowania mówcy, który dopiero w holistycznej pajdeutyce obejmującej zagadnienia politycznej práxis byłby $\mathrm{w}$ stanie wykształcić nie tylko odpowiednie umiejętności wytwórcze, ale również odpowiednie cnoty praktyczne i wreszcie samą mądrość polityczną. Mając na względzie poczynione powyżej uwagi, a w pamięci ogólną charakterystykę retorycznej dyspozycji oraz jej celu, należy rozpoznać istotę powiązania sztuki przekonywania oraz mądrości politycznej z perspektywy pajdeutycznych wykładni trzech przywołanych myślicieli.

Jeśli chcemy umieścić retorykę w kontekście pajdeutycznym, powinniśmy postrzegać ją $\mathrm{w}$ charakterze modelu kształtowania cnót politycznych oraz wspomagania dyspozycji intelektualnych, które to przymioty dojrzałego mówcy miałyby stanowić uwarunkowanie dla wytwarzania mów nie tylko przekonywujących, ale także roztropnych i skierowanych ku temu, co szlachetne, sprawiedliwe i prawe. Chaim Perelman w pierwszym rozdziale Imperium retoryki podkreśla specyficzne nastawienie antycznego mówcy do przedmiotu, o którym ten traktował - próbując bowiem wytworzyć w słuchaczach określone przekonanie, starał się on

\footnotetext{
${ }^{1}$ Używane przez Arystotelesa na określenie środków przekonywania słowo písteis oznaczało zarówno „wytwarzanie przekonań”, jak i „wzbudzanie zaufania”.

${ }^{2}$ Arystoteles wyróżnił trzy rodzaje mów ze względu na cel: doradcze - przekonywały one o pożytku lub szkodzie płynącej z podjęcia pewnych działań; sądownicze dowodzące o słuszności lub niesłuszności oskarżeń z uwagi na wydarzenia przeszłe; epidejktyczne - chwalące bądź ganiące pewne cechy charakteru, postawy czy postępowanie. Niezależnie od rodzaju mowy, konsekwencją przekonania było podjęcie bądź zaniechanie pewnych działań: ustanowienie prawa, skazanie oskarżonego, kształtowanie i powielanie postaw etycznych.
} 
uprawdopodobnić przedstawiane mniemania, które nie były podbudowane żadną pewną wiedzą, lecz raczej stanowiły przedmiot dyskusji i miały charakter prawdopodobny. Grecy określali tego typu przekonania terminem eúlogos, wskazującym na to, co godne i warte przyjęcia ze względu na pewne dobro, do którego te przekonania się odnosiły i do którego realizacji miały się przyczyniać (Perelman 2004, 14). Jeśli potraktujemy retorykę jako sztukę podtrzymywania eulogosu, która nadto opierała się na eubolii, tj. słusznym rozumowaniu, znajdziemy odpowiednie argumenty na rzecz uznania sztuki perswazji za istotny element mądrości politycznej.

\section{Platońska retoryka a alethós politiké téchne}

Filozoficzne dociekania mające określić istotę i cel retoryki, które zainicjował w swojej wczesnej twórczości Platon stanowiły polemiczną odpowiedź na propozycje sofistycznych nauczycieli oratorstwa. Warto zauważyć, że pojęcia takie, jak: filozof, retor czy sofista nie miały jeszcze $w$ tamtych czasach doprecyzowanych definicji, zaś rozróżnienie odbywało się często poprzez odniesienie do zakresów wiedzy, umiejętności, ale także przez wskazanie intencji filozofa, sofisty czy retora (por. Retoryki: 1355b 17-18), ich moralnej konstytucji oraz sposobu postrzegania polityki i działalności obywatelskiej (por. McCoy 2007, 1-22). Dlatego też Platon nie był skłonny do całkowitego deprecjonowania, którejkolwiek $\mathrm{z}$ wymienionych sztuk, umiejętności czy profesji, lecz podkreślał znaczenie intelektualnych oraz etycznych predyspozycji czyniących je wartościowymi z punktu widzenia przybranego przez niego rozumienia sztuki politycznej, którą najprościej określić można, przywołując wypowiedź Sokratesa, jako:

[...] pracę nad udoskonaleniem dusz współobywateli i walkę, która zawsze mówić każe to, co najlepsze; wszystko jedno, czy to będzie miłe, czy niemiłe słuchaczom (Gorgiasz 503a).

W przeciwieństwie do Protagorasa dla Platona „miarą” wszechrzeczy nie byłby każdy człowiek, ale ten, kto osiągnął znawstwo, czyli opanował wiedzę i sztukę w danej dziedzinie (Teajtet 178b). W dialogu Protagoras filozof poddawał krytyce polityczną edukację sofisty, odmawiając jego pajdei miana sztuki (Protagoras 319a). Tym samym, jak sugeruje Werner Jaeger, odmawiał 
jej również miana mądrości, jako że w tym przypadku episteme oraz techne miały być w zasadzie tożsame (Jaeger 2001, 690). Właściwe ugruntowanie sztuki politycznej widział natomiast w filozofii (Politeia $473 \mathrm{c}$-d), najpierw tej sokratejskiej, etycznej, później zaś tej, która pozwalała osiągnąć wiedzę o bytach niezmiennych i niezniszczalnych - o ideach.

Kontynuując proces rozliczania dotychczasowych poglądów na temat polityki i retoryki oraz ich korelacji, Platon w dialogu Gorgiasz krytykował nie tyle umiejętność perswazyjnego mówienia w ogóle, co raczej jej sofistycznie określony cel (postrzegany jako polityczne nadużycie), który zbudowana na wątpliwych fundamentach krasomówcza retoryka realizowała. W tym kontekście Platon postrzegał retorykę jako pseudosztukę i sztukę pozorną, która opierała się na błędnych założeniach politycznych (czy raczej w ogóle braku politycznej wiedzy), prowadząc w konsekwencji do skutków niepożądanych i wręcz szkodliwych dla dusz poszczególnych obywateli oraz całej wspólnoty (Jaeger 2001, 690-691; Wesoły 2009, 19-21). W innym dialogu, Fajdrosie, czytamy:

A jak taki retor, który nie wie, co jest dobre i złe, a ma przed sobą zgromadzenie, które także tego nie wie, i on je przekonywa i nakłania - [...] - ale jeśli on zło przedstawi jako dobro, a dbając o opinię tłumu, nakłoni ich do czynu złego, zamiast do dobrego, to jak myślisz, jaki plon zbierze sztuka retoryczna $\mathrm{z}$ takiego posiewu? (260c).

Platon wykazuje w tym fragmencie, że współcześni mu nauczyciele wymowy, po pierwsze: nie dążyli do zbudowania warsztatu retorycznego na wiedzy oraz wartościach dobra i piękna, lecz odwoływali się co najwyżej do potocznych mniemań i populizmów, poglądów o charakterze kontrowersyjnym i relatywnym, kierując się prawdopodobieństwem zaledwie, podług Protagorejskiej zasady anthrópos métron; po drugie: poruszając się wśród ogólnej ignorancji, nie potrafili uczynić nic, by ją przemóc, ponosząc tym samym pajdeutyczną porażkę. Wyuczana przez nich umiejętność skłaniania słuchaczy do przyjęcia przekonań mówcy miałaby być niczym kosmetyka dla ciała - powierzchowną ułudą krasomówstwa ukrywającą rzeczywiste braki w znajomości tego, do czego w mowach swoich się odnosili, znajomości tego, co jest dobrem dla dusz współobywateli. Platonowi nie chodziło zatem o to, aby z retoryki całkowicie zrezygnować, ale by zbudować ją na solidnych 
fundamentach odpowiedniej wiedzy, mądrości politycznej, co uczyniłoby z niej sztukę sensu stricto. Należy w końcu podkreślić, że wszelka krytyka retoryki płynęła z krytyki źle rozumianej polityki. Jeśli dobrem określano, jak to czynił Kallikles, zaszczyty i pragnienie władzy oraz czynienie tego, co się komu żywnie podobało (Gorgiasz 481b-486d), w konsekwencji z retoryki uczyniono narzędzie pochlebstwa, ułudę prawdy i szlachetności. Kiedy bowiem Platon w Gorgiaszu nazywał retorykę „iluzją części polityki” (463e), mówił o takim jej użyciu, które pozostaje w sprzeczności z zasadami proponowanej przez niego alethós politiké téchne, czyli prawdziwej sztuki politycznej, sformułowanej powyżej jako troska o dusze obywateli. Zatem wszelkie użycie retoryki, które zmierzało poprzez pochlebstwa do pozyskiwania publiki dla celów niegodnych, pozorów prawości i sprawiedliwości, było uchybieniem względem sztuki politycznej. Natomiast perswazja płynąca z politycznej mądrości mająca na celu dobro wspólnoty obywatelskiej byłaby traktowana jako wytwór prawdziwej sztuki retorycznej, a także politycznej sztuki retorycznej (Juchacz 2004, 212).

Sugerując się powyższym fragmentem, wywnioskować można, że Platon widział $\mathrm{w}$ polityce (jako epistéme i téchne) coś więcej niż tylko działalność obywatelską związaną z rządzeniem, sądzeniem i sprawowaniem urzędów. Na pierwszy plan wysuwała się bowiem troska o dusze obywateli, która zogniskowała się w Platońskim pajdeutycznym modelu stanowiącym oczywiście wyraz alethós politiké téchne. Model „polityka” jako tego, który poucza i pobudza do myślenia przedstawiony został m.in. w dialogach Obrona Sokratesa, Gorgiasz, Protagoras czy Politeia. Natomiast podporządkowanie alethós politiké téchne mądrości politycznej i uczynienie z niej narzędzia takiego mędrca, czy konkretnie filozofa, dokonało się w utworze Fajdros. Platon dostrzegał konieczność szlifowania umiejętności perswazji pod warunkiem, iż mówca zyskał uprzednio odpowiednie atuty intelektualne i etyczne. Sam korzystał z rozwiązań, których skuteczność retoryczna praktyka wykazała - Platoński Sokrates posługiwał się retorycznymi metodami, np. argumentem z prawdopodobieństwa (eikós) czy autoprezentacją wynikającą z charakteru mówcy (ethopoiía) (McCoy 2007, 3-4). Platon nie traktował retoryki jak przypadkowego, okazjonalnie podnoszonego narzędzia, lecz stanowić miała dla niego sztukę, rozumową umiejętność, która swoje 
podwaliny uzyskała dzięki umiejscowieniu w Platońskim zamyśle pajdeutycznym o charakterze psychagogicznym, czyli duszowódczym. Platon chciał, by retoryka nie była utożsamiana $\mathrm{z}$ samymi tylko technicznymi możliwościami (Fajdros, 268d-269c), lecz by stanowiła element szerszej wiedzy i umiejętności (tamże, 270d-e). Z rozmowy Sokratesa z Fajdrosem dowiadujemy się, dlaczego retoryka była ważnym elementem pajdei i na jakiej powinna opierać się wiedzy, by zasługiwać na miano sztuki i mądrości.

Fakt, że pomimo krytyki retoryki we wczesnych dialogach, Platon podejmuje próbę zbudowania jej na fundamentach mądrości politycznej, świadczy o tym, że doceniał jej zalety jako sztuki właśnie - rozumianej we właściwym tego słowa rozumieniu -, tzn. takiej dziedziny wytwórczej, która opierając się na określonej wiedzy, dzięki użyciu właściwych środków prowadzi do obranego celu. Tym celem miało być: „prowadzenie dusz ludzkich za pomocą mów, i to nie tylko w sądach i jakie tam inne zebrania czy zgromadzenia publiczne, ale i w prywatnych kółkach" (Fajdros, 261a-b). Retoryka w służbie Platońskiej politiké téchne miała stanowić zarówno element praktyki obywatelskiej, jak i jedną $\mathrm{z}$ metod pomocniczych na wstępnym etapie edukacji, kiedy to dusza ucznia nie była jeszcze gotowa na odbiór subtelnych wywodów oraz przeprowadzanie dialektycznych polemik. Perswazyjna mowa miała być niejako „przypomnieniem wywołanym w duszach pełnych wiedzy" (278a-b; por. Yunis 2007, 75-76).

W dialogu Fajdros Platon przekonywał, że oprócz gruntownej wiedzy odnośnie tematyki, o której mówca traktuje (czyli nade wszystko, oprócz mądrości politycznej), powinien on wykazać się także znajomością różnych rodzajów dusz i umiejętnością rozpoznawania ich w osobach konkretnych słuchaczy i uczniów, do których się zwracał tak, by móc tym skuteczniej do nich dotrzeć (tamże, 271d; 277b-c). Tylko ten, kto uprawiałby retorykę nadbudowaną na powyższych rozumnych fundamentach, był wyposażony $\mathrm{w}$ sztukę realizującą cel ze wszech miar szlachetny, jakim jest przekonywanie do tego, co prawdziwe i słuszne $\mathrm{w}$ świetle alethós politiké téchne czy też prawdziwej politycznej mądrości.

Zawiedziony ustrojem demokratycznym, nie wykluczał wprawdzie możliwości korzystania $\mathrm{z}$ retoryki także $\mathrm{w}$ pozapajdeutycznej działalności politycznej, jednakże w Politei wyraźnie opowiadał się przeciwko źle pojętej 
isegorii, która przyznając wszystkim obywatelom równe prawo do zabierania głosu w kwestiach publicznych, otworzyła drogę pozorom praworządności ukrytym pod „pstrokatym płaszczem” pseudosztuki wymowy. I choć ten pogląd wraz z upływem czasu stał się bardziej umiarkowany - Platon zaczął bowiem dostrzegać, że istniały różne formy demokracji: zdrowe i zwyrodniałe (Juchacz 2004, 93) - ostatecznie w jego projekcie politycznym i pajdeutycznym retoryka ograniczyła się do bycia narzędziem mędrców, czy raczej „miłośników mądrości”, prowadzących rozważania w dość hermetycznym i elitarnym gronie Akademików.

\section{Izokratejska lógon paideía}

Izokrates, uczeń sofistów i słuchacz Sokratesa, inaczej niż Platon rozumiał miejsce retoryki w pajdei obywatelskiej oraz inaczej postrzegał charakter i zadania filozofii. Polemizując $\mathrm{z}$ Platonem, zaproponował alternatywne rozumienie ostatniego terminu, a jego wykładnia zakładała ścisłe powiązanie retoryki z filozofią, które de facto oznaczało ich utożsamienie. Retoryka dla Izokratesa była również sztuką i wiedzą, lecz podczas gdy dla Platona retoryka pozostawała służebną względem sztuki politycznej oraz dialektyki, zdaniem Izokratesa stanowiła samą mądrość polityczną i filozofię właśnie. Wyrazem najwyższej mądrości i roztropności było bowiem według niego zaangażowanie w sprawy publiczne podług zaleceń pajdei słowa (lógon paideía). Konkurencyjność znaczenia Izokratejskiej filozofii realizowała się w odmiennym od Platońskiego punkcie widzenia na kwestie związane $\mathrm{z}$ edukacją, polityką oraz retoryką i, jak pisze Jaeger, Izokrates sprzeciwiał się w ten sposób Platońskiemu zawłaszczeniu terminu „filozofia” (Jaeger 2001, 965; por. Jebb 1893, 34-50) proponując własne jej ujęcie. Uważał, że filozofia powinna stać się udziałem całego ateńskiego ludu, wykształconego podług ideałów proponowanej przez niego retorycznej pajdei - pajdei logosu. Izokrates utożsamiał filozofię z potęgą logosu, zaś lógos rozumiał przede wszystkim jako substancję politycznej kultury Greków (Papillon 2007, 66). Sądził, że to właśnie jego wychowankowie, a nie akademicy Platona, otrzymają bardziej adekwatne do uprawiania sztuki politycznej wychowanie (Sinko 1959, 753). Izokrates nie skupiał się na zagadnieniach teoretycznych, lecz 
interesowała go wiedza $\mathrm{w}$ jej praktycznym wykorzystaniu - filozofia jako polityczna kultura, która powinna być rozwinięciem przymiotów umysłu i charakteru (Izokrates, Przeciw sofistom, 15, 21).

W mowie zwanej Panegirykiem Izokrates podkreślał, że nie ma większej chwały nad tą, jaką daje poświęcenie się sprawom publicznymi (Papillon 2007, 64). Był przekonany, że retoryka jako wyraz mądrości praktycznej i pajdei słowa będzie skutecznym urzeczywistnieniem filozofii, głosem w sprawach ważnych z perspektywy dobra całej polis (tamże). Na potwierdzenie przywoływanych poglądów przytoczę dwie poniższe wypowiedzi:

Sądzę, że i wszelkie sztuki i nauka wymowy wtedy osiągają duże postępy, jeśli się podziwia i czci nie tych, nie tych, którzy położyli podwaliny pod te sztuki, ale tych którzy w sposób najdoskonalszy je realizują [...] (Izokrates 1996, 370).

Ludzie mający pretensje do sławy retorycznej, powinni przestać pisać o depozytach i o innych tego rodzaju głupstwach, a zacząć współzawodniczyć z tą mową i zastanowić się, jak ułożyć na ten sam temat mowę lepszą od mojej, w przekonaniu, że dobrze zapowiadającym się nie wypada rozwodzić się nad drobnymi tematami ani mówić o rzeczach, które nie przyniosą słuchającym korzyści życiowej, ale o planach, których realizacja przyniesie uwolnienie od obecnych nieszczęść i stanie się źródłem wielkich dobrodziejstw dla innych (Izokrates 1996, 410).

Według Izokratesa sztuka retoryczna miała przynosić prawdziwe korzyści dla polis i stanowić realne wsparcie $\mathrm{w}$ rozwiązywaniu bieżących problemów. Praktykowanie sztuki wymowy i perswazji przedkładał ponad teoretyczne rozważania nad nią, gdyż to właśnie w praktyce widział wyraz mądrości, jaką niosła ze sobą retoryka. Zdrowy rozsądek oraz cnoty obywatelskie cenił Izokrates ponad wszystko widząc w nich ugruntowanie politycznej perswazji. Jak pisze Tadeusz Sinko w Zarysie historii i literatury greckiej:

Ten właśnie zdrowy rozsądek kazał mu $\mathrm{z}$ paradoksów Sokratesa i sokratyków wziąć nie tylko niechęć do chełpliwych obietnic sofistów i ich mechanicznych sposobów nauki, ale także żądanie, by uczniowie zastanawiali się nad treścią mów i reprezentowali pewną pozytywną moralność, wszystko to dla dobra państwa, którym mieli rządzić (Sinko 1959, 756).

Retoryczna praktyka będąca owocem Izokratejskiej pajdei słowa, czyli opartego na sztuce perswazji modelu wychowawczego, stanowić miała 
wprowadzenie do „racjonalnej kultury ducha” (Sinko 1959, 757). Stanowiła dla niego prawdziwą filozofię, mądrość polityczną jako działalność obywatelską. Oczywiście, osadzając mądrość polityczną głęboko w wymiarze praktycznym, Izokrates uczynił z retoryki jej kluczowy element, bez którego byłaby ona co najwyżej teoretycznym modelem.

Jako wychowawca był realistą i w mowie Przeciw sofistom $(1 ; 10)$ krytykował tych, którzy obiecywali zbyt wiele w dziedzinie pajdei (także Jaeger 2001, 973). W przeciwieństwie do Sokratesa i Platona nie wierzył, że wiedza jest warunkiem cnotliwego postępowania:

Niech nikomu się nie wydaje, że ja myślę, iż sprawiedliwości można nauczyć. Jestem przekonany, że nie istnieje żadna taka metoda, która ludziom o złych skłonnościach odwodzących ich od cnoty może wszczepić panowanie nad sobą i sprawiedliwość. Ale nauka wygłaszania mów politycznych najlepiej przygotuje i wychowa do tego rodzaju cnót (Przeciw sofistom, 21).

Linia wychowawców prowadząca do Izokratesa była zatem linią phrónesis i eúlogosu, jako że bazowała na dostępnym każdemu Grekowi doświadczeniu i zdroworozsądkowej, opartej na powszechnie uznawanych mniemaniach mądrości (Papillon 2007, 60-61; Sinko 1959, 753), która nie porywając się na poszukiwanie obiektywnej wiedzy, kierowała się wszakże zawsze zaleceniami słusznego namysłu oraz roztropnymi opiniami ludzi uczonych i doświadczonych - o tym, co dobre i sprawiedliwe, podług założenia o mnogości i różnorodności zapatrywań na kwestie związane z etycznością i polityką. Można dojść do wniosku, iż mądrość polityczna Izokratesa nie była raczej określoną wiedzą, lecz raczej doświadczeniem i praktycznym nastawianiem, a realizowała się przede wszystkim w działalności mówców, zarówno wychowawców, jak i zaangażowanych w sprawy wspólnoty obywateli.

To powiązanie natury (predyspozycji) i sztuki (rozumianej jako praktyka i doświadczenie) dawało nadzieje na uzyskanie pozytywnych efektów wychowawczych wśród uczniów, którzy nie tyle podlegali retorycznej pajdei, ale także sami ją kultywowali, jednocześnie pracując nad własnym doskonaleniem się w cnocie obywatelskiej. Sam Izokrates dawał wyraz nadziei dotyczących pajdeutycznego charakteru retoryki w treści swych mów, w które, niezależnie od tematu przewodniego, wplatał swego rodzaju „manifesty 
wychowawczo - polityczne", będące $\mathrm{z}$ jednej strony rozliczeniem $\mathrm{z}$ propozycjami innych nauczycieli retoryki, z drugiej natomiast zachętą do nieustannego doskonalenia się i zaangażowania w sprawy publiczne (Tuszyńska-Maciejewska 1991, 61). Ponadto starał się odeprzeć zarzut o amoralność retoryki i - podobnie jak Gorgiasz - uważał, że nauczyciel retoryki przekazywał swoją wiedzą, by uczniowie korzystali z niej w sposób prawy, nie ponosząc odpowiedzialności za jej ewentualne niewłaściwe wykorzystanie:

W rzeczy samej amoralny charakter retoryki był głównym zarzutem przeciwko niej. Izokrates niejednokrotnie zajmuje stanowisko, które u Platona zajmuje Gorgias, że mianowicie nauczyciel przekazuje uczniom swoją sztukę, by sprawiedliwie z niej korzystali, i że nie może być przedmiotem nagany, jeśli uczeń jej nadużywa (Jaeger 2001, 975).

Według zaleceń stworzonej przez Izokratesa pajdei słowa, sztuka retoryczna miała w sposób konieczny wiązać się z doskonaleniem charakteru i ćwiczeniem się w cnocie politycznej. Postulaty Izokratesa były z pewnością bliższe obywatelom ateńskim, jako że zdrowy rozsądek czy pewna roztropność przemawiały doń bardziej niż wyrafinowane, niezrozumiałe dla większości, wywody Platona. Były poniekąd kontynuacją sofistycznego zainteresowania wychowaniem obywatelskim (zwłaszcza w modelu Gorgiaszowym) (Jaeger 2001, 963), ale również spuścizną etycznej i politycznej pajdei propagowanej we wcześniejszych wiekach przez Solona czy Klejstenesa, a następnie Peryklesa i Efialtesa (Jaeger 2001, 966; Sinko 1959, 763). Retoryka Izokratesa zapewniła zatem owym ideom ciągłość, hołdując przede wszystkim greckiej ufności w roztropność i słuszne mniemania autorytetów. ${ }^{3}$

3 Odnośnie do prymatu roztropności (phrónesis) i mądrości (sophía) wśród innych tzw. cnót intelektualnych (dianoetycznych) wypowiedział się Arystoteles w VI ks. Etyki Nikomachejskiej (1143b). Arystoteles analizując w Topikach termin éndoxa, czyli słuszne mniemanie, wyjaśnił, że éndoxa zwykle są to albo poglądy dzielone przez wszystkich, albo przez większość, albo przez mędrców (ew. przez tych, którzy słyną ze swej szlachetności i dobrej opinii - Topiki, 100b; por. Berti 1979, 249; Most 1994, 176). Pomimo zbieżności terminów używanych przez Izokratesa i Arystotelesa nie można na tej kanwie porównywać ich rozumienia sztuki perswazji. Podczas gdy éndoxa mogłyby stanowić u obu mędrców treść retorycznych mów, u Arystotelesa stanowią wyłącznie pewne tematy, zaś to entymem, czyli wnioskowanie, jest „substancją przekonywania” (Retoryka 1354a). Phrónesis natomiast wedle poglądów Arystotelesa stanowi intelektualną cnotę deliberatywną kształtującą wyłącznie 


\section{Arystotelesowska retoryka jako odrośl polityki}

Poglądy Izokratesa, spotkały się z krytyką Arystotelesa, który jeszcze podczas pierwszego pobytu w Akademii sformułował zasady własnej retoryki i, jeśli wierzyć przekazom historycznym, to właśnie Izokratejski model retorycznej pajdei stał się ku temu naczelną pobudką. ${ }^{4}$ Systematyzując dostępny mu materiał empiryczny (Natali 2013, 24) Arystoteles stworzył własną koncepcję retoryki jako sztuki, czyli trwałej dyspozycji do metodycznego odnajdywania tego, co w odniesieniu do każdego przedmiotu może być przekonywujące (Retoryka, 1355b). Choć traktat Retoryka odnosi się do sztuki przekonywania jako dyscypliny autonomicznej względem dziedzin teoretycznych czy praktycznych ${ }^{5}$, w księdze I Arystoteles zauważył, że wiąże się ona poniekąd z polityką i dialektyką (Retoryka, 1356a), i to właśnie pokrewieństwo wobec tej pierwszej wydaje się nader interesujące z perspektywy niniejszych rozważań. W toku wywodu Arystoteles zauważył, że retorykę jak każde dobro służące do realizacji wyższych celów, można było wykorzystać w sposób niegodziwy i szkodliwy, zwłaszcza, jeśli nie szła w parze $\mathrm{z}$ odpowiednim wychowaniem (1355b, 1356a). Dlatego też tak istotnym było jej powiązanie z dziedziną polityki oraz prawem.

Polityka była dla Arystotelesa najwyższym „pułapem” mądrości praktycznej, deliberatywnej, która zajmowała się kwestiami związanymi z namysłem nad tym, co roztropne, słuszne i sprawiedliwe, co prowadzi do realizacji dobra jako celu, sądzeniem oraz działaniem $\mathrm{w}$ zakresie praktyki obywatelskiej. Sztuka retoryczna, jak wiele innych umiejętności wytwórczych, miała być jej podległą i dostarczać metodycznych rozwiązań wspomagających działalność polityczną (Etyka Nikomachejska, 1094a-b); także Most 1994, 168

etyczne i polityczne práxis, a nie retoryczne poíesis (Etyka Nikomachejska, 1138b 1140a).

${ }^{4}$ Carlo Natali przywołuje na potwierdzenie tej tezy świadectwa Filodemosa i Cycerona oraz samego Arystotelesa ( $O$ dowodach sofistycznych), które mają świadczyć nie tylko o wczesnych dociekaniach tego ostatniego w temacie retoryki, ale również mają być dowodem na polemiczny charakter Arystotelesowskiego traktatu o retoryce (lub przynajmniej jego fragmentów) i niezgodzie na proponowany przez Izokratesa model polityczno-retoryczny filozofii (Natali 2013, 28-29; za: Berti 1999, 149).

${ }^{5}$ Więcej na temat podziału na dziedziny teoretyczne, praktyczne i wytwórcze można znaleźć w księdze VI Etyki Nikomachejskiej, księdze I Metafizyki oraz Topikach. Obszernie komentuje te kwestie Enrico Berti w książce Profilo di Aristotele (Berti 1979, 239-251) oraz Marian Wesoły w artykule „Natura - człowiek - sztuka w koncepcji Arystotelesa" (Wesoły 2002, 121-146). 
- 169). W związku z tym, że w efekcie namysłu praktycznego dochodziło do określenia pewnych mniemań (éndoxa) o charakterze normatywnym, retoryka będąc narzędziem perswazji stanowiła element politycznej dynamiki oraz realizacji istoty deliberacji wyboru tego, co słuszne i odpowiednie dla danej wspólnoty (Halliwell 1994, 215). Zarówno dziedziny praktyczne, jak i sztuki, także retoryka, nie odnosiły się do tego, co konieczne, lecz tego, co prawdopodobne czy opcjonalne. Arystoteles był przy tym przekonany, że nie istnieje jedno dobro wspólne czy jedna droga jego osiągania, a to, co dobre dla wspólnoty niekoniecznie będzie dobrem dla każdej jednostki (Berti 1979, 248-249). Toteż retoryka stanowiła dla Arystotelesa techniczny element procesów politycznych zmierzających do perswadowania i utrzymywania w mocy pewnych przekonań (dóxai), które już były bądź miały szanse stać się tymi słusznymi i godnymi wyboru (éndoxa).

Specyfika działalności politycznej wymaga jednak szczególnych kompetencji od mówcy, by mógł on przekonywać i wzbudzać zaufanie audytorium. Retor powinien przejawiać następujące walory intelektualne i praktyczne: odznaczać się roztropnością (phrónesis), szlachetnym charakterem (areté) oraz dobrą wolą (eúnoia) (Retoryka, 1378a). Roztropność była tym rodzajem rozumowania, które pomagało podejmować słuszne przekonania i działać w sposób prawy, stanowiąc przy tym normatywny ogranicznik dla wyboru środków do obranych celów praktycznych (Etyka Nikomachejska 1141b-1142a; Berti 1979, 262-263). To właśnie uwarunkowanie utrzymywało retorykę w ryzach mądrości praktycznej, balansując roztropność ze stosownością środków dostarczanych przez sztukę perswazji. Propozycja Arystotelesa rozumiana jako ograniczenie amoralnego charakteru retoryki mogłaby stanowić klucz do mądrego i skutecznego uprawiania polityki. Następnie, szlachetny charakter przejawiał się w trwałych dyspozycjach, zwanych cnotami lub dzielnościami i wraz z roztropnością stanowił o etycznej i politycznej doskonałości. Jednakże cnota polityczna i etyczna niekoniecznie zawsze szły w parze, co sugerowałby przywoływany już powyżej fragment książki Bertiego. W związku z tym retoryczna przemyślność pozwalałaby mówcy dokonać odpowiedniej selekcji spośród cech charakteru mogących wspomóc bądź zaszkodzić przekonaniu słuchaczy (por. Rapp 2012, 603-605). Właściwa autoprezentacja była bowiem kluczowa w kontekście 
kreowania wiarygodności niezbędnej do wzbudzania przekonania, zwłaszcza w kwestiach natury praktycznej (tamże) ${ }^{6}$. Dobra wola na koniec gwarantowała, że przymioty naszego rozumu oraz charakteru mogły przekładać się na współpracę $\mathrm{z}$ innymi obywatelami w celu realizowania celów wspólnoty. W sposób oczywisty przekładała się na wzbudzanie zaufania audytorium powodowanego nierzadko czysto afektywną reakcją (Rapp 2012, 604).

Należy jeszcze na koniec podkreślić, że z lektury Retoryki wynika, że sztuka perswazji sama $\mathrm{w}$ sobie nie implikowała $\mathrm{z}$ konieczności wartości praktycznych, a obecny $\mathrm{w}$ retoryce éthos, czyli środki przekonywania wynikające $\mathrm{z}$ charakteru mówcy, pozostawał jak ona cała amoralny. Arystoteles był świadom nadużyć płynących z uprawiania sztuki perswazji i nie miał wątpliwości, że sytuacje takie były nieuniknione $\mathrm{z}$ uwagi na instrumentalny, neutralny etycznie charakter retoryki. Neutralny charakter sztuki retorycznej wynikał po pierwsze $\mathrm{z}$ jej technicznej natury metodycznego poszukiwania tego, co przekonywujące w każdym przedmiocie; po drugie z "ograniczonej" celowości - cel retoryki tkwił bowiem w przekonywaniu, zatem jej zadaniem jest przedstawienie przekonywującej mowy odnośnie danego przedmiotu. Skuteczność w posługiwaniu się sztuką retoryczną zależała przede wszystkim od właściwego (orthós) doboru środków przekonywania i do tej kwestii ogranicza się w swojej celowości.

Immanentny cel sztuki retorycznej, jakim było wytworzenie przekonywującej mowy, nie stanowił wszakże celu samego w sobie w rozumieniu przyjętym przez Arystotelesa ze względu na klasyfikację dóbr realizowanych przez ludzi. Wytwory sztuki perswazji służyły do urzeczywistnienia celu nadrzędnego wyznaczanego przez refleksję o charakterze praktycznym:

Zdawałoby się, że [najwyższe dobro - przyp. AM] jest przedmiotem nauki naczelnej i najbardziej kierowniczej. Za taką zaś uchodzi polityka, nauka o państwie. Ona bowiem orzeka, które nauki należy w państwie uprawiać i których się kto ma uczyć, i w jakiej mierze: widzimy też, że pod nią podpadają te właśnie umiejętności, które najwyżej cenimy, jak sztuka dowodzenia, sztuka gospodarowania i retoryka. Skoro zaś ta nauka używa do swego celu wszystkich innych umiejętności praktycznych, a ponadto rozstrzyga o tym, co należy czynić, a

${ }^{6}$ O definicyjnych różnicach cnoty w Etykach i Retoryce zob. Makowski 2012, 88-96. 
czego zaniechać, to cel jej musi obejmować cele wszystkich innych [umiejętności], tak że cel ten musi być najwyższym dobrem człowieka (Etyka Nikomachejska, 1094b).

Retoryka dostarczała środków przekonywania, natomiast cel, w imię którego była użytkowana, był wyznaczany poprzez namysł (boúlesis) i deliberację (proaíresis), prowadzących do podjęcia określonych wyborów natury praktycznej, etycznej i politycznej (por. Shields 2007, 381).7 W VII księdze Polityki wyjaśnił w następujący sposób powyższą zależność polityki i sztuki:

Dwa są warunki, od których zależy wszelkie powodzenie. Jeden z nich polega na tym, aby cel i zadanie działania zależycie wytknąć, drugi zaś, aby znaleźć wiodące do celu działanie. Oba warunki mogą być zgodne ze sobą, ale też i niezgodne; czasem mianowicie wytknie się trafnie cel, ale działa się błędnie, tak że się go nie osiąga, niekiedy zaś stosuje się właściwe środki działania, ale cel pozostaje błędnie wytknięty, niekiedy znów błądzi się w jednym i drugim względzie, jak [zdarza się] np. w sztuce lekarskiej. (...) We wszystkich kunsztach i umiejętnościach należy $\mathrm{w}$ jednym i $\mathrm{w}$ drugim kierunku być biegłym, a więc i w ustalaniu celu, i w stosowaniu środków wiodących do celu (Arystoteles, Polityka, $1331 \mathrm{~b}) .^{8}$

W Etyce Nikomachejskiej Arystoteles podkreślał, że jeśli celem praktycznych działań jest osiągnięcie pewnego celu, jakim jest dobro, to powodzenie nie jest możliwe bez pewnej dyspozycji do wynajdywania odpowiednich środków do zrealizowania celu. Tą dyspozycją jest przemyślność czy wynalazczość (deinótes), która jest podstawą sztuk, a zatem i retoryki:

Owóż istnieje pewna zdolność zwana sprytem (deinótes); polega ona na umiejętności trafnego wyboru środków zmierzających do obranego celu i na umiejętności osiągania go. Zdolność to pochwały godna, jeśli cel jest moralnie piękny; jest ona jednak chytrością, jeśli cel jest zły; dlatego sprytnymi nazywamy zarówno ludzi rozsądnych, jak ludzi chytrych. Rozsądek nie jest identyczny z tą zdolnością, ale nie istnieje bez niej (Arystoteles, Etyka Nikomachejska,1144a).

\footnotetext{
7 Stąd też, twierdził Arystoteles, sofistyka, rozumiana jako "retoryczne nadużycie" była kwestią wyboru czy preferencji (Retoryka, 1355b).

8 Tę kwestię podkreśla również Glenn W. Most, kiedy sugeruje, iż Arystoteles prezentował swoim studentom zagadnienia retoryczne $\mathrm{w}$ formie kursu, który miał zapewnić im powodzenie $w$ perswazji zarówno na polu filozoficznym, jak i praktycznym: „If Aristotle's students have been well trained philosophically in ethics and politics, they will be able to pursue philosophically respectable ends in their political activity, insofar as they engage in this latter; but if they are not trained in rhetoric, they will not be competent in the means necessary to reach those goals (Most 1994, 184)."
} 
Choć sama sztuka perswazji pozostawała neutralną etycznie, traktat Arystotelesa nie był kolejnym podręcznikiem retoryki czy zwykłym zbiorem technicznych wskazówek. Proponowana przez niego sztuka perswazji była z jednej strony rewizją wcześniejszych prób jej ujmowania, a z drugiej koncepcją autorską umocowaną wśród innych założeń Arystotelesowskiego systemu, zwłaszcza rozważań dotyczących dialektyki, cnót dianoetycznych oraz zagadnień praktycznych: etycznych i politycznych.

Teksty Stagiryty traktujące o retoryce były nie tylko systematyzacją metod i środków perswazji, ale korygowały również pewne zaniedbania poczynione głównie przez Izokratesa, także sofistów, a nawet swojego mistrza, Platona. Już na kartach Protreptyku, wczesnego dzieła będącego swego rodzaju zachętą do poświęcenia się filozofii, Arystoteles rozprawił się z Izokratejską retoryką jako rzekomą filozofią praktyczną, przekonując, że nie można zrezygnować z poszukiwań prawdziwej mądrości, także w perspektywie działalności politycznej. Swoją tezę systematycznie podpierał właśnie poprzez konstruowanie sieci wzajemnych powiązań pomiędzy dociekaniami teoretycznymi, działalnością praktyczną i sztukami. Najprawdopodobniej uważał, że to właśnie filozof byłby osobą najbardziej kompetentną do napisania traktatu retorycznego, gdyż posiadł wcześniej wszelkie potrzebne do tego kompetencje (Most 1994, 188). Christof Rapp argumentuje ponadto na rzecz stanowiska, że retoryka w ujęciu Arystotelesa nie była dziedziną konkurencyjną względem filozofii, lecz stanowi rozwinięcie pewnej innej dyscypliny niezwykle istotnej z perspektywy argumentowania i dowodzenia, dialektyki (Rapp 2012, 591) ${ }^{9}$.

Arystoteles zgadzał się poniekąd z Platonem w kwestii wpływu, jaki perswazyjna mowa miała na dusze słuchaczy i rozwinął ten wątek w studium charakterów i afektów. Normatywnie rzecz ujmując, Arystoteles odradzał praktykowanie zwodzenia słuchaczy, a zwłaszcza wprowadzania w błąd sędziego, szczególnie poprzez nadużycie pathosu, tj. środków perswazji

\footnotetext{
${ }^{9}$ Eksponując powiązanie dialektyki i retoryki, Arystoteles zasygnalizował interesującą i istotną kwestię, mianowicie: to, co dobre i prawdziwe miało być łatwiejsze do udowodnienia i bardziej wiarygodne, natomiast retoryka dążąc do uprawdopodobnienia opierała się na tych samych umiejętnościach, które prowadziły do tego, co prawdziwe i dobre, a choć mówca mógł w swojej niegodziwości przekonywać do rzeczy wprost przeciwnych, czynił to z większą trudnością (Retoryka, 1355a)
} 
wywołujących w słuchaczach reakcje afektywne, lecz zachować je co najwyżej do wzmocnienia siły argumentu ucieleśnionego w entymemie (Retoryka, 1354a). Potwierdził przez to, w duchu psychagogii, iż kształtowanie dusz, poprzez perswadowanie pewnych opinii i mniemań, czy to $\mathrm{w}$ procesie edukacji, czy w ramach praktyki obywatelskiej, odbywało się nie tylko poprzez ich wygłaszanie, ale także poprzez oddziaływanie na słuchaczy osobowością mówcy i pobudzanie ich uczuć, sam bowiem lógos był niewystarczający (Rapp 2012, 593-595). Uzupełnił ponadto Platońskie stanowisko o aspekt wprowadzający realne powiązanie polityki z retoryką (Fortenbaugh 2007, 109), poruszając m.in. kwestie budowania zaufania i wzbudzania wiarygodności w demokratycznej práxis (Sinko 1959, 769). Jego manifest w Protreptyku, z gruntu pajdeutyczny, obnażał potrzebę wszechstronnego kształcenia obywateli, rozbudzającego wszelkie dzielności rozumu i charakteru, gdyż tylko takie podejście pozwalałoby $\mathrm{z}$ największym prawdopodobieństwem oczekiwać pozytywnych rezultatów pajdeutycznych w kształceniu obywateli polis (Protreptyk, 2;8).

\section{Literatura}

Arystoteles 2008. Etyka Nikomachejska. Warszawa: Wydawnictwo Naukowe $\mathrm{PWN}$.

Arystoteles 2008. Polityka. Warszawa: Wydawnictwo Naukowe PWN.

Arystoteles 1988. „Protreptyk“. Symbolae Philologorum Posnaniensium Graecae et Latinae VII. Poznań: Adam Mickiewicz University Press, s. 55-73.

Arystoteles 2004. Retoryka. Warszawa: Wydawnictwo Naukowe PWN.

Arytoteles 1978. Topiki. Warszawa: Wydawnictwo Naukowe PWN.

Berti, E. 1979. Profilo di Aristotele. Roma: Edizioni studium, s. 138-148; s. 239268.

Bons, J. A. E. 2007. „Gorgias the Sophist and Early Rhetoric.“ W: Worthington I. (Ed.) A Companion to Greek Rhetoric. Malden: Blackwell Publishing, s. 37-46.

Fortenbaugh, W. W. 2007. „Aristotle's Art of Rhetoric.“ W: Worthington I. (Ed.) A Companion to Greek Rhetoric. Malden: Blackwell Publishing, s. 107123.

Halliwell, S. 1994. „Popular Morality, Philosophical Ethics, And the Rhetoric.“ W: Furley, D. J. \& Nehamas, A. (Eds.) Aristotle's Rhetoric. New Jersey: Princeton University Press, s. 211-230.

Hansen, M. H. 1991. The Athenian Democracy in the Age of Demosthenes. Oxford, Cambridge: Blackwell. 
Izokrates 2007. „Przeciw sofistom“. Meander 3-4/07: 235-238. Warszawa: Komitet Nauk o Kulturze Antycznej PAN.

Izokrates 1996. „Panegiryk.“ Filomata 439/440: 368-410. Kraków: Wydawnictwo Naukowe PWN.

Jaeger, W. 2001. Paideia. Formowanie człowieka greckiego. Warszawa: Fundacja Aletheia.

Janik, J. 2012. Political Concepts And Language of Isocrates. Kraków: Towarzystwo Wydawnicze „Historia Iagellonica“.

Juchacz, P. W. 2004. Sokrates. Filozofia $w$ działaniu. Poznań: Wydawnictwo Naukowe Instytutu Filozofii UAM.

Makowski, P. 2012. „DYNAMIS. Metafizyczne pojęcie możności i jego rola w filozofii praktycznej Arystotelesa." Diametros 33 (wrzesień 2012): 76-100. Kraków: Wydawnictwo UJ.

McCoy, M. 2008. Plato On the Rhetoric of Philosophers and Sophists. New York: Cambridge University Press.

Mielcarski, C. 2010. Sofiści i polityka. Warszawa: Wydawnictwo Naukowe PWN. Most, G.W. 1994. „The Use of Endoxa: Philosophy And Rhetoric in the Rhetoric." W: Furley, D. J. \& Nehamas, A. (Eds.) Aristotle's Rhetoric. New Jersey: Princeton University Press, s. 167-192.

Natali, C. 2013. Aristotle: His Life and School. New Jersey: Princeton University Press.

Papillon, T.L. 2007. „Isocrates.“ W: Worthington I. (Ed.) A Companion to Greek Rhetoric. Malden: Blackwell Publishing, s. 58-74.

Perelman, Ch. 2004. Imperium retoryki. Retoryka i argumentacja. Warszawa: Wydawnictwo Naukowe PWN.

Platon 1922. Gorgiasz. Lwów - Warszawa: Książnica Polska T-wa Naucz. Szkół Wyższych.

Platon 2006. Fajdros. Warszawa: Unia Wydawnicza „Verum“.

Platon 2006. Politeia. Kęty: Wydawnictwo Antyk Marek Derewiecki.

Platon 1991. Protgoras. Warszawa: Wydawnictwo Recto.

Rapp, Ch. 2012. „Aristotle on the Moral Psychology of Persuasion.“ W: Shields,

Ch. (Ed.) The Oxford Handbook of Aristotle. New York: Oxford University Press, s. 589-611.

Reale, G. 2005. Historia filozofii starożytnej. Tom I. Lublin: Redakcja Wydawnictw Katolickiego Uniwersytetu Lubelskiego.

Sekstus Empiryk 2007. Przeciw uczonym. Kęty: Wydawnictwo Marek Derewiecki.

Shields, Ch. 2007. Aristotle. New York: Routledge.

Sinko, T. 1959. Zarys historii literatury greckiej. Tom I: Literatura archaiczna i klasyczna. Warszawa: PWN, s. 752-772.

Thomas, C.G. \& Webb, E.K. 1994. „From Orality to Rhetoric: An Intellectual Transformation." W: Worthington, I. (Ed.) Persuasion: Greek Rhetoric in Action. London: Routledge, s. 3-25. 
Tuszyńska - Maciejewska, K. 1991. „Pochwała Heleny w wykonaniu ateńskiego mówcy Izokratesa." Symbolae Philologorum Posnaniensium Graecae et Latinae VIII: 57-70. Poznań: Adam Mickiewicz: University Press.

Wardy, R. 1996. The Birth of Rhetoric: Gorgias, Plato, And Their Successors. London: Routlegde.

Wesoły, M. 2009. „Platona Gorgiasz - kompozycja dramatyczna, zarzewie agonu i sokratejska wymowa." W: Pacewicz, A. (red.) Kolokwia Platońskie ГОРГІАД. Wrocław: Instytut Filozofii Uniwersytetu Wrocławskiego. Wydawnictwo Alta 2, s. 14-25.

Yunis, H. 2007. „Plato's Rhetoric.“ W: Worthington I. (Ed.) A Companion to Greek Rhetoric. Malden: Blackwell Publishing, s. 75-89. 


\title{
Aleksandra Mathiesen
}

(Adam Mickiewicz University in Poznań, aleksandramathiesen@gmail.com)

Rhetorical Education As a Component Of the Formation of Political Wisdom

\begin{abstract}
The revolutionary concept of rhetoric introduced by Plato not only stood firmly against the oratorical practices of his times, but also established first "scientific" art of rhetoric applicable into the frames of philosophical paideia. His perception of rhetorical tasks was strictly related to the goals of political formation and was absolutely indispensable for the purposes of a pursuit of political wisdom, in its exceedingly distinctive meaning. Plato initiated a century-long dispute on rhetorical ends and its political - paideutic value. First, criticized by Isocrates, later, resumed in the most exceptional treatise of Aristotle, he delineated a path of a new display of educational value of the art of rhetoric.
\end{abstract}

Keywords: art of rhetoric, rhetorike techne, rhetorical education, paideia, political wisdom

Ethics in Progress (ISSN 2084-9257). Vol. 7 (2016). No. 2, Art. \#5, pp. 58-81.

Creative Commons BY-SA 3.0

Doi: 10.14746/eip.2016.2.5 